\title{
The Role of Work Environment and Leadership on Employee Performance through Employee Work Discipline
}

\author{
Debby, Umi Farida, Hasan Nongkeng \\ Sekolah Tinggi Ilmu Ekonomi AMKOP Makassar, Indonesia \\ debby@gmail.com, farida.unm@gmail.com, hasannongkeng@gmail.com \\ Muhammad Ybnu \\ Universitas Tomakaka, Mamuju, Indonesia \\ ibnutaufan25@gmail.com \\ La Ode Abdul Salam Al Amin \\ Baubau Islamic School of Religion (STAI) \\ salambaubau@gmail.com \\ Sianturi Novdin Manoktong \\ Civil Engineering, Technology Management and Environmental Science \\ sianturinovdin@gmail.com \\ Yusriadi Yusriadi \\ Sekolah Tinggi Ilmu Administrasi Puangrimaggalatung, Makassar, Indonesia \\ yusriadi.yusriadi@uqconnect.edu.au
}

\begin{abstract}
Work discipline is one of the factors that can reflect the performance produced by employees. This study was designed as survey research. The approach used in this research is quantitative research. It conducted this research at the Department of Industry and Trade of Central Mamuju Regency. This study's population were all Department of Industry and Trade of Central Mamuju Regency employees, amounting to 26 people. The data collection techniques used in this research were interviews, a list of questions, and documentation. The work environment plays a positive and significant role in work discipline at the Office of Trade and Industry in Central Mamuju District. Thus, it can conclude that the work environment will play a role in work discipline. Leadership has a positive and significant role in work discipline at the Office of Trade and Industry in Central Mamuju District. Thus, it can conclude that leadership will maintain work discipline.
\end{abstract}

Keywords: Work Environment, Leadership, Employee Performance, Work Discipline

\section{Introduction}

Work environment and leadership factors play a role in work discipline and employee performance. In the above explanation, work discipline also plays a role in employee performance. Wibowo (2012) and Hasibuan (2011) state that the higher achievement motivation and work discipline is the employee performance will also increase. According to Sedarmayanti (2011), one factor that plays a role in implementation is mental attitude (work motivation, work discipline, work ethics). The mental attitude possessed by an employee will give a role in his account.

From the research results, it can be concluded that work discipline has a significant role in employee performance. Furthermore, in Sumiati Paramban (2018), from the results of the research, it can be concluded that work discipline plays a significant role in employee performance. Physical environmental conditions, the current working environment conditions at the Office of Trade and Industry in Central Mamuju Regency are less comfortable. The environment has a narrow space so that in carrying out work activities, employees are not concentrated due to noise in the narrow room and make the room unheard. Then the workspace, in the workspace arrangement, is very untidy. Judging from the 
room's irregular structure makes people confused in finding a place to do the activities they do. Based on observations made at the Department of Trade and Industry in Central Mamuju Regency regarding leadership, leaders are still deemed not to approach and motivate their employees directly. They are less successful because the task is not what the administration expected.

Employee discipline is a nation's or people's attitude toward labour. Individuals in the community who see labour as a noble thing for human existence will have a strong work ethic. Conversely, attitudes and perspectives on work as something of poor importance for life will automatically result in a low work ethic. Work ethic is a set of positive behaviours rooted in fundamental beliefs accompanied by a total commitment to an integral work paradigm. According to him, if a person, an organization, or a community adheres to the work paradigm, believes committed to the work paradigm, all of that will give birth to their distinctive work attitudes and behaviours. That will be the Work Ethic and culture. Thus, work discipline is the foundation of authentic success. His study of sociological studies influences this view since the time of Max Weber in the early twentieth century and management writings of the last twenty years, which all lead to one main conclusion; human, especially work behaviour, determine that success in various areas of life. Some people refer to this work behaviour like motivation, habit (habit) and work culture.

The phenomenon related to employees' performance at the Department of Trade and Industry in Central Mamuju Regency is that work is still not running optimally. This can be seen in terms of quality. There are still many employees who do not have the ability according to their field of work. The Trade and Industry Service employees in Central Mamuju Regency still need additional employees to add employees in each section. Coaching for the Office of Trade and Industry employees in Central Mamuju District still needs to be improved.

\section{Methods}

This research design is a survey, namely analyzing facts and data that support the information needed to support the research discussion in solving and answering the main problems proposed, namely the influence of work ethic and work experience on employee performance through job satisfaction. In this study, there are two categories of data: qualitative data and quantitative data: 1) Qualitative data, that is, data in words, sentences, schemes, and images, such as literature and theories linked to the author's research. The qualitative data in this study constitute a general description of the research object. 2) Quantitative data is information expressed in numerical scale or numbers, such as qualitative data scored (scoring) based on questionnaire responses. This research was designed as survey research (survey research). The approach used in this research is quantitative research. This research was conducted at the Department of Industry and Trade of Central Mamuju Regency. This study's population were all 26 employees of the Department of Industry and Trade of Mamuju Tengah Regency. The data collection techniques used in this research were interviews, a list of questions, and documentation.

\section{Results}

\subsection{The Role of the Work Environment on Work Discipline}

The role of work environment variables on work discipline is positive. This means that an increase in the work environment will be followed by an improvement in work discipline, assuming other factors that play a role in the work environment's size are considered constant. This research shows that there is a positive and significant role of the work environment on work discipline.

Table 1. The effect of Work Environment and Performance on Work Discipline

\begin{tabular}{|c|c|c|c|c|c|c|}
\hline \multicolumn{7}{|c|}{ Coefficients } \\
\hline \multicolumn{2}{|c|}{ Model } & \multicolumn{2}{|c|}{ Unstandardized Coefficients } & \multirow{2}{*}{$\begin{array}{c}\text { Standardized } \\
\text { Coefficients }\end{array}$} & \multirow[t]{2}{*}{$\mathrm{t}$} & \multirow[t]{2}{*}{ Sig. } \\
\hline & & $\mathrm{B}$ & Std. Error & & & \\
\hline \multirow{3}{*}{1} & (Constant) & .754 & 1.170 & & .166 & .553 \\
\hline & Work Environment & .641 & .134 & .360 & 3.511 & .000 \\
\hline & Performance & 241 & .125 & .111 & 1.020 & .003 \\
\hline
\end{tabular}

This study also supports the results of previous research from Miftachul Mujib (2016), the conclusion that the work environment plays a positive role in employee work discipline. Furthermore, Kristian Dwi Nugroho (2015) conducted 
research based on the results of the study. It can be concluded that the work environment has a significant role positive and effective towards work discipline (Nuraini et al., 2019; Umanailo, 2020, 2019). Then research conducted by Tri Wahono (2016), based on the study results, can be concluded that the work environment plays a role in employee work discipline. The work environment's managerial implication for work discipline is obedience and obedience to the workplace's norms and regulations. It is namely by improving the work environment utilizing the work atmosphere, namely the conditions around employees who are doing work that can contribute to the work's implementation. The relationship with co-workers, namely the association with co-workers, is harmonious and without intrigue among fellow workers. The availability of work facilities, namely equipment used to support complete/up-to-date work. Lighting, namely light or lighting, is very beneficial for employees to get safety and smoothness of work and security at work, which is to keep the place and work environment safe.

The goals to be achieved must be clear and ideally set as well as challenging enough for employees' abilities. This means that the purpose (job) assigned to an employee must be in accordance with the ability of the employee concerned. But if the job is beyond his ability or the job is far below his ability, the employee's seriousness and discipline will be low. Here lies the importance of the principle of the right man in the right place and the right man in the right job.

\subsection{The Role of the Work Environment on Employee Performance through Work Discipline}

This study shows a positive and significant role of the work environment on employee performance through work discipline. This can be seen from the path analysis of the indirect part of the work environment through work discipline, which has a significant role in employee performance. Thus, work discipline can manage the work environment on employee performance.

Table 2. The effect of Employee Performance on Work Discipline

\begin{tabular}{|c|c|c|c|c|c|c|}
\hline \multicolumn{7}{|c|}{ Coefficients } \\
\hline \multirow{2}{*}{\multicolumn{2}{|c|}{ Model }} & \multicolumn{2}{|c|}{ Unstandardized Coefficients } & \multirow{2}{*}{$\begin{array}{c}\text { Standardized } \\
\text { Coefficients } \\
\text { Beta }\end{array}$} & \multirow[t]{2}{*}{$\mathrm{t}$} & \multirow[t]{2}{*}{ Sig. } \\
\hline & & B & Std. Error & & & \\
\hline \multirow{2}{*}{1} & (Constant) & 6.60 & 1.511 & & 1.351 & .011 \\
\hline & $\begin{array}{l}\text { Employee } \\
\text { performance }\end{array}$ & .35 & .151 & .166 & 1.425 & .000 \\
\hline
\end{tabular}

The work discipline's managerial implication on employee performance through work discipline is that work discipline with an employee attitude that is obedient and obedient to the norms and regulations. The workplace can manage the work environment with everything around the employee, either physically or physically. non-physical which can act as employees when working towards employee performance with an employee attitude that is obedient and obedient to the norms and regulations set by the workplace.

This study shows a positive and significant role of leadership on employee performance through work discipline. This can be seen from the results of the path analysis. The indirect part of leadership through work discipline has a significant role in employee performance. Thus, work discipline can play a leadership in employee performance.

The managerial implication of the role of leadership on employee performance through work discipline is that work discipline with an employee attitude who is obedient and obedient to the norms and regulations set by the workplace can play leadership by the process of acting, mobilizing, motivating, and directing those who exist within the organization/agency to achieve goals for employee performance with an employee attitude that is obedient and obedient to the norms and regulations set by the workplace

The role of work discipline variables on employee performance is positive. This means that an increase in work discipline will be followed by an improvement in employee performance, assuming other factors that play a role in the size of work discipline are considered constant. This research shows that there is a positive and significant role of 
work discipline on employee performance. This can be seen from the results of the analysis of the direct role path. The results of work discipline have a positive and significant role on employee performance.

This study's results are in line with the statements of Wibowo (2012) and Hasibuan (2011), which state that the higher achievement motivation and work discipline, the employee performance will also increase. According to Sedarmayanti (2011), one factor contributing to performance is mental attitude (work motivation, work discipline). Work ethics). The mental attitude possessed by an employee will give a role in his account. Work discipline is one of the factors that can reflect the version produced by employees.

\section{Discussion}

The role of the leadership variable on work discipline is positive. This means that an increase in leadership will be followed by an improvement in work discipline, assuming other factors that play a role in administration are considered constant. This research shows that there is a positive and significant role of leadership in work discipline. This study also supports the results of previous research from Jeli Nata Liya (2017), the conclusion that leadership plays a positive and significant role in employee work discipline. Furthermore, research conducted by Alfonso F. Nazar (2017), based on the study results, can be concluded that leadership has a positive and significant role on employee work discipline. Then the research conducted by Elkana (2014), based on the study results, it can be concluded that there is a significant role between leadership and employee work discipline.

Managerial implications on the role of leadership on work discipline are an attitude of obedience and obedient to the norms and regulations that the workplace has set, namely by increasing leadership utilizing analysis, namely the leader can analyze in determining steps in achieving goals. Diagrammatic, namely administration in Arranging steps to attain goals, must be programmed, structured, and conceptualized, then decisions. In the implementation of decision-making, leaders dare to take risks. Finally, assertiveness, that is, leaders in decision-making must be firm without compromise so that their subordinates respect them.

The role of work environment variables on employee performance is positive. This means that an improvement will follow an increase in the work environment in employee performance, if other factors that play a role in the size of the work environment are considered constant. This research shows that there is a positive and significant role of the work environment on employee performance. This can be seen from the results of the direct role path analysis. The effects of the work environment have a positive and significant role on employee performance.

This study's results are in line with the statement of Nitisemito (2010), which states that the work environment is everything that is around the worker and can play a role in carrying out his assigned tasks. The work environment consists of physical and non-physical environments attached to employees so that they cannot. According to Sedarmayanti (2011), the physical work environment is all physical conditions around the workplace that can play a role in employee performance either directly or indirectly. Nitisemito (2010) The factor that can play a role in keeping employees in one organization is the existence of a work environment in a harmonious relationship among co-workers. Cooperative relationships and kinship are one of the factors that can contribute to employee performance.

This study also supports the results of previous research from Diana Khairani Sofyan (2013), the conclusion that there can be a significant role between work environment and employee work performance. Furthermore, research conducted by Arta Adi Kusuma (2013), based on the study results, can be concluded that the work environment has a role in employee performance. The research conducted by Rodi Ahmad Ginanjar (2013), based on the study results, can be concluded that there is a positive and significant role between the work environment and employee performance.

The role of the leadership variable on employee performance is positive. This means that an increase in leadership will be followed by an improvement in employee performance, assuming other factors that play a role in administration are considered constant. This research shows that there is a positive and significant role of leadership on employee performance. This can be seen from the direct role path analysis results, which show that leadership has a positive and vital role in employee performance.

This study's results are in line with the statement of Hasibuan (2002), which states that leadership is a way for a leader to act on the behavior of subordinates to cooperate and work effectively and efficiently to achieve organizational goals. Leadership is the ability to take on other parties. The success of a leader depends on his ability to play this role. 
According to Subiyandono (2011), in strategic management for an organization that wants to develop rapidly, human resource management functions, leadership, work discipline, motivation, and organizational culture and work field must be combined.

This study also supports the results of previous research from Danang Setya Ramadhani (2016), the conclusion that there is a positive role between leadership and employee performance. Furthermore, research conducted by Fenny Dwi Oktavia (2014), based on the study results, can be concluded that administration has a role in employee performance. Wijayanti undertook the research. Dwi Wahyu (2012), based on the study results, can be concluded that there is a leadership role in employee performance.

Discipline is the awareness and willingness of a person to obey all applicable social rules and norms. Discipline is a mental attitude that is reflected in the actions or behavior of individuals, groups, or society, in the form of obedience to regulations set by the government or the ethics, norms and rules that apply in society for certain purposes (Mu'adi et al., 2020; Nawawi et al., 2020). Discipline can also be interpreted as self-control so as not to do something that is contrary to the philosophy of a nation / state. The definition of work is burden, obligation, source of income, pleasure, prestige, self-actualization, and so on. Work is the use of mental and physical processes in achieving several productive goals.

The managerial implication of the work environment on employee performance is the quality and quantity of work results achieved by employees. In carrying out their duties following their responsibilities, they improved the work environment utilizing the work atmosphere, namely the conditions around employees who are doing work that can play a role. The relationship with co-workers, namely the association with co-workers, is harmonious and intrigue among fellow workers. Work facilities are available, namely the equipment used to support the smooth running of work complete / up to date, then illumination, namely light or very lighting. Great benefits for employees to get a safe and smooth job are to keep the place and work environment in a safe condition.

This study also supports the results of previous research from Nathalia, Diansari (2016), the conclusion that work discipline variables have a significant role in employee performance variables. Furthermore, research conducted by Marsyaf Rinaldi (2016), based on the study results, can be concluded that discipline work has a significant role on employee performance. Then research conducted by Sumiati Paramban (2018), based on the study results, can be concluded that work discipline plays a significant role in employee performance.

The managerial implication of the role of work discipline on employee performance is the quality and quantity of work results achieved by employees in carrying out their duties following their responsibilities. They increased work discipline by way of an exemplary leader. That is, the leadership has a good field so that subordinates also have good discipline. Good too, then remuneration, because compensation will give employees satisfaction and love for their workplace. The justice, namely justice, which is the basis for policy in providing payment or punishment, will create good discipline. Assertiveness, namely the leadership's firmness in taking action, will play a role in employee discipline. Finally, human relations, a harmonious humanitarian relationship between fellow employees, contribute to creating a good organization.

\section{Conclusion}

The work environment plays a positive and significant role towards work discipline at the Office of Trade and Industry in Central Mamuju Regency. Thus, it can be concluded that the work environment will maintain work discipline. Leadership plays a positive and significant role in the Office of Trade and Industry in Central Mamuju Regency. Thus, it can be concluded that the administration will maintain work discipline. The work environment plays a positive and significant role in employees' performance at the Office of Trade and Industry in Central Mamuju Regency. Thus, it can be concluded that the work environment will play a role in employee performance. Leadership has a positive and significant role in employees' performance at the Office of Trade and Industry in Central Mamuju District. Thus, it can be concluded that leadership will play a role in employee performance. The work environment plays a positive and significant role in employee performance through work discipline in the Office of Trade and Industry in Central Mamuju Regency. Thus, it can be concluded that the work environment will play a role in employee performance through work discipline. Leadership plays a positive and significant role in employee performance through work discipline in the Office of Trade and Industry in Central Mamuju Regency. Thus, it can be concluded that leadership will play a role in employee performance through work discipline. Work discipline plays a positive and significant 
Proceedings of the International Conference on Industrial Engineering and Operations Management Sao Paulo, Brazil, April 5 - 8, 2021

role in employees' performance at the Office of Trade and Industry in Central Mamuju Regency. Thus, it can be concluded that work discipline will play a role in employee performance.

\section{References}

Alfonso F. Nazar. 2017. Peranan Kepemimpinan Terhadap Disiplin Kerja Karyawan Pada Posmetro Mandau Duri. Jurnal Wira Ekonomi Mikroskil Volume 7, Nomor 02, Oktober 2017.

Arta Adi Kusuma, 2013. Peranan Motivasi dan Lingkungan Kerja Terhadap Kinerja Karyawan Hotel Muria Semarang. Jurusan Manajemen Fakultas Ekonomi. Universitas Negeri Semarang

Cooper, Donald R dan C. William Emory, 2004. Metode Penelitian Bisnis. Jilid 1,. Edisi kelima. Penerjemah: Dra. Ellen Gunawan, M.A., dan Iamam. Nurmawan, S.E. Jakarta. Erlangga.

Danang Setya Ramadhani. 2016. Peranan Kepemimpinan Dan Motivasi Terhadap Kinerja Pegawai Di Balai Pengembangan Kegiatan Belajar (BPKB) Daerah Istimewa Yogyakarta (DIY). Program Studi Pendidikan Administrasi Perkantoran Jurusan Pendidikan Administrasi Fakultas Ekonomi Universitas Negeri Yogyakarta

Diana Khairani Sofyan. 2013. Peranan Lingkungan Kerja Terhadap Kinerja Pegawai BAPPEDA. Malikussaleh Industrial Engineering Journal Vol.2 No.1 (2013) 18-23

Elkana. 2014.Peranan Kepemimpinan Terhadap Disiplin Kerja Pegawai Pada Kantor Kecamatan Damai Kabupaten Kutai Barat. http://ejurnal.untag-smd.ac.id/index.php/PD/article/view/815

Fadel.,Muhammad, K. Toruan Rayendra L. 2009. Reinventing Local Goverment, Pengalaman Dari Daerah. Jakarta: Elex Media Komputindo

Fenny Dwi Oktavia. 2014. PerananKepemimpinan Dan Disiplin Kerja Terhadap Kinerja Karyawan Pada Dinas Pendidikan Kota Bengkulu. Universitas Bengkulu Fakultas Ekonomi Dan Bisnis Jurusan Manajemen. http://repository.unib.ac.id/8269/1/I,II,III,I1-14-fen-FE.pdf

Ghozali, Imam. 2011. Aplikasi Analisis Multivariatedengan program SPSS, Badan Penerbit Universitas Diponegoro, Semarang.

Jeli Nata Liyas. 2017. Peranan Kepemimpinan Terhadap Disiplin Kerja Karyawan Pada PT. Bank Syariah Mandiri. JEBI (Jurnal Ekonomi dan Bisnis Islam)-Volume 2, Nomor 2, Juli-Desember 2017

Kristian Dwi Nugroho. 2015. Peranan Lingkungan Kerja dan Motivasi Kerja terhadap Disiplin Kerja Pegawai Negeri Sipil di Dinas Pengelolaan Pasar Kota Surakarta.https://digilib.uns.ac.id/dokumen/detail/48111/

Marsyaf Rinaldi. 2016 Peranan Disiplin Kerja Dan Etos Kerja Serta Gaya Kepemimpinan.Situasional Terhadap Kinerja Pegawai Di Kantor Badan Penanggulangan Bencana Daerah Kota Palu.e Jurnal Katalogis, Volume 4 Nomor 10, Oktober 2016 hlm 160-167

Mas'ud, Fuad. 2011. Survai Diagnosis Organisasional Konsep \& Aplikasi. Badan Penerbit Universitas Diponegoro. Semarang

Miftachul Mujib. 2016. Peranan Lingkungan Kerja Dan Komitmen Terhadap Disiplin Kerja (Studi pada Pegawai Badan Kepegawaian Daerah Daerah Istimewa Yogyakarta). Program Studi ManajemenFakultas EkonomiUniversitas Negeri Yogyakarta

Mu'adi, S., Maksum, A., Hakim, M. L., \& Umanailo, M. C. B. (2020). Transfer of function agricultural land. Proceedings of the International Conference on Industrial Engineering and Operations Management, 0(March), 2568-2574.

Nathalia, Diansari. 2016. Peranan Disiplin Kerja Terhadap Kinerja Pegawai Dinas Perikanan Dan Kelautan Provinsi Jawa Barat. https://repository.widyatama.ac.id/xmlui/handle/123456789/8335

Nawawi, Hadari. 2005, Manajemen Sumber Daya Manusia Untuk Bisnis Yang Kompetitif, Cetakan Ke-4, Gajah Mada Univercity Press, Yogyakarta

Nawawi, M., Ali, A., Irawan, B., Ahmad, B., Mukramin, S., Marsuki, N. R., Umanailo, M. C. B., \& Kaya, I. R. G. (2020). The village kalesang program as a poverty alleviation community. International Journal of Scientific and Technology Research, 9(3), 3103-3107.

Nuraini, N., Riadi, A., Umanailo, M. C. B., Rusdi, M., Badu, T. K., Suryani, S., Irsan, I., Ismail, I., Pulhehe, S., \& Hentihu, V. R. (2019). Political Policy for the development of Education. International Journal of Scientific \& Technology Research, 8(10).

Rodi Ahmad Ginanjar. 2013. Peranan Lingkungan Kerja Terhadap Kinerja KaryawanPada Dinas Pendidikan, Pemuda Dan OlahragaKabupaten Sleman. Program Studi Manajemen PendidikanJurusan Administrasi PendidikanFakultas Ilmu PendidikanUniversitas Negeri Yogyakarta.https://eprints.uny.ac.id

Tri Wahono. 2016. Peranan Lingkungan Kerja Dan Motivasi Kerja Terhadap Kedisiplinan Kerja Pegawai Pada UD. Sari Bumi Di Sragen. Program Studi Pendidikan Manajemen Fakultas Ekonomi Dan Bisnis Universitas Muhammadiyah Surakarta. http://eprints.ums.ac.id/50970/1/Naskah\%20publikasi.pdf 
Umanailo, M. C. B. (2019). Structure of Social Change in Industrial Society. Proceedings of the International Conference on Industrial Engineering and Operations Management Riyadh, 668-672.

Umanailo, M. C. B. (2020). The energy in the context of social. Proceedings of the International Conference on Industrial Engineering and Operations Management, 0(March), 2503-2508.

Wijayanti, Dwi Wahyu. 2012. PerananKepemimpinan dan Motivasi Kerja Terhadap Kinerja Karyawan PT. Daya Anugerah Semesta Semarang.Skripsi.Jurusan Manajemen. Fakultas Ekonomi. Universitas Negeri Semarang.https://lib.unnes.ac.id/18042/1/7350407081.pdf

\section{Biographies}

Debby is a student at Magister Program of Economic Science of STIE AMKOP, Indonesia. Her areas of interest and research include social science and economic. She has published some articles in national journals.

Umi Farida is a lecturer at Economics Department of STIE AMKOP, Indonesia. Her areas of interest and research include economic, management, management human resource. She has published some books and many articles in national and international journals.

Hasan Nongkeng is a lecturer at the Management Department, Faculty of Business, and Economics, STIE AMKOP, Makassar. He has published some books and many articles in national and international journals. He is also a reviewer and editor in some local and international journals.

Muhammad Ybnu is a lecture at Management Department of Universitas Tomakaka, Indonesia. His areas of interest and research include social science, economic and public administration. He has published some articles in national and international journals.

La Ode Abdul Salam Al Amin, He is a lecturer at the YPIQ Baubau Islamic School of Religion (STAI). S1, Economics Education Department. Dayanu Ikhsanuddin Baubau University. and Masters Degree in Management. Sultan Agung Islamic University Semarang. Currently, he is actively publishing his written works in national journals. $\mathrm{He}$ is also active in social activities in the City of Baubau

Sianturi Novdin Manoktong graduated with a Bachelor of Civil Engineering from the Medan Institute of Technology (ITM) in 1997 and graduated from the Master of Technology Management at the University of North Sumatra (USU) in 2001 and graduated from ESERI's Philosophy of Doctor Program, Universiti Sultan Zainal Abidin (UniSZA) Terengganu, Malaysia in the year 2020.email sianturinovdin@gmail.com, I want to be professional so I have a passion for Civil Engineering, Technology Management and Environmental Science

Yusriadi Yusriadi is a lecturer at Public Administration Department of Sekolah Tinggi Ilmu Administrasi Puangrimaggalatung, Indonesia and chancellor on Sekolah Tinggi Ilmu Hukum Pengayoman. His areas of interest and research include social science, political science, sociology, legal studies, and public administration. He has published some books and many articles in national and international journals. He is a reviewer and editor in some local and international journals. 